\title{
DISTRIBUSI BERAS BULOG PASCA BANSOS RASTRA DAN BANTUAN PANGAN NON TUNAI
}

\author{
Yusup Rachmat Hidayat \\ Fakultas Ilmu Sosial dan Manajemen \\ Institut Ilmu Sosial dan Manajemen STIAMI \\ Email : yusup.rachmat@gmail.com
}

ARTICLE INFO
Keywords:
Bansos Rastra,
Bantuan Pangan Non Tunai
$(B P N T)$,

Distribusi Beras BULOG

\section{ABSTRACT}

Penelitian ini bertujuan mengetahui kinerja opersional distribusi beras oleh BULOG setelah bantuan pemerintah untuk program kesejahteraan dan ketahanan pangan nasional yang sejak lama bernama Program Beras untuk Rakyat Miskin (Raskin) beralih menjadi Program Bantuan Sosial Beras Sejahtera (Bansos Rastra) dan Program Bantuan Pangan Non Tunai (BPNT). Metode penelitian yang digunakan adalah gabungan antara kuantitatif dan kualitatif, dimana gabungan kedua metode analisa ini cocok digunakan untuk menganalisa data yang berupa angka dan diagram serta data yang berupa kebijakan dan peraturan pemerintah. Adapun sumber data penelitian adalah data sekunder yang diperoleh dari kajian beberapa jurnal, artikel, peraturan pemerintah, data perusahaan, internet dll. Yang dianggap relevan dengan topik bahasan penelitian. Hasil penelitian menunjukkan adanya pengaruh secara langsung terhadap kinerja operasional kegiatan distribusi beras BULOG, termasuk pengaruh kepada beberapa kegiatan operasional lainnya akibat perubahan kebijakan bantuan pangan pemerintah khusunya melalui Program BPNT. Penelitian ini menyarankan kepada BULOG untuk meningkatkan, mengembangkan serta mengoptimalkan kegiatan usaha komersialnya untuk mempertahankan dan meningkatkan keinerja operasional dan pendapatannya pasca Progam Bansos Rastra dan Program BPNT.

\section{PENDAHULUAN}

Pemerintah Indonesia telah sejak lama melakukan intervensi terkait bahan pangan pokok, khususnya beras yang tujuannya untuk ketahanan pangan nasional dan meningkatkan kesejahteraan masyarakat berpendapatan rendah. Bentuk intervensi yang dilakukan pemerintah berupa memberikan bantuan pangan yang diantaranya subsidi bahan pangan pokok dan bantuan sosial bahan pangan pokok beras.

Pemerintah dalam memberikan bantuan telah sejak lama menugaskan BULOG dalam hal distribusi pangan. BULOG sebuah akronim dari Badan Urusan Logistik merupakan salah satu Badan Usaha Milik Negara (BUMN) berbentuk Perusahaan Umum dimana salah satu bidang usahanya bergerak pada bidang manajemen logistik pangan, dengan mengutamakan fungsi tugas pelayanan Publik/Publis Service Obligation (PSO) untuk menjamin ketersediaan, keterjangkauan dan stabilitas komoditas bahan pangan pokok. 
Menurut Peraturan Pemerintah Nomor 17 Tahun 2015 tentang Ketahanan Pangan dan Gizi didefinisikan beberapa maksud, diantaranya sebagai berikut :

i. Pangan adalah segala sesuatu yang berasal dari sumber hayati produk pertanian, perkebunan, kehutanan, perikanan, peternakan, perairan, dan air, baik yang diolah maupun tidak diolah yang diperuntukkan sebagai makanan atau minuman bagi konsumsi manusia, termasuk bahan tambahan Pangan, bahan baku Pangan, dan bahan lainnya yang digunakan dalam proses penyiapan, pengolahan, dan/atau pembuatan makanan atau minuman.

ii. Ketahanan Pangan adalah kondisi terpenuhinya Pangan bagi negara sampai dengan perseorangan, yang tercermin dari tersedianya Pangan yang cukup, baik jumlah maupun mutunya, aman, beragam, bergizi, merata, dan terjangkau serta tidak bertentangan dengan agama, keyakinan, dan budaya masyarakat, untuk dapat hidup sehat, aktif, dan produktif secara berkelanjutan.

iii. Pangan Pokok adalah Pangan yang diperuntukkan sebagai makanan utama sehari-hari sesuai dengan potensi sumber daya dan kearifan lokal.

iv. Distribusi Pangan adalah suatu kegiatan atau serangkaian kegiatan untuk menyalurkan pasokan Pangan secara merata setiap saat guna memenuhi kebutuhan Pangan masyarakat.

BULOG dalam melakukan kegiatan logistik melakukan pengelolaan manajemen logistik yang diantaranya pengadaan, persediaan, perawatan stock, pemerataan stock, distribusi dan lain-lain.

Donald Walters (2003:3-4), pengertian logistik adalah fungsi yang melibatkan perpindahan, mengatur perpindahan barang, dan penyimpanan material dalam perjalanannya dari pengirim awal, melalui rantai pasok dan sampai ke pelanggan akhir.

Subagya (1994), menyatakan bahawa manajemen logistik merupakan suatu ilmu dan seni yang mempelajari proses kegiatan merencanakan dan menentukan kebutuhan pengadaan, penyimpanan, penyaluran dan pemeliharaan serta penghapusan material/alat.

Dalam hal persediaan menurut Eko (2005:4), menyatakan manajemen persediaan adalah kegiatan yang berhubungan dengan perencanaan, pelaksanaan dan pengawasan penentuan kebutuhan material sedemikian rupa". Dalam hal distribusi menurut Martono (2015:288), distribusi merupakan pergerakan barang dan Jasa dari pemasok hingga konsumen akhir melalui distribution channel (saluran distribusi).

Saluran distribusi sendiri menurut Tjiptono (2014:295), merupakan serangkaian partisipan organisasional yang melakukan semua fungsi yang dibutuhkan untuk menyampaikan produk / jasa dari penjual ke pembeli akhir. Berdasarkan kajian uraian diatas tentang pengertian logistik dan pengertian manajemen logisitik, maka dapat disimpulkan bahwa manajemen logistik merupakan ilmu dan seni berupa stategi serangkaian kegiatan pengelolaan barang melalui berbagai tindakan yang diantaranya perencanaan, pengadaan, penyimpanan, pemeliharaan, penyaluran dan penghapusan untuk mencapai tujuan yang telah ditetapkan. 
BULOG sebagai BUMN dalam hal menentukan keputusan dan kebijakan terkait pengadaan, persediaan dan pendistribusian bahan pangan, tidak dapat menentukan semua keputusan dan kebijakan secara sendiri sepenuhnya.Terdapat mekanisme dan koordinasi antar Kementerian/Lembaga Pemerintah dari pusat hingga daerah. Terlebih lagi selama ini, kinerja operasional BULOG sangat bergantung dan didominasi oleh pelaksanaan tugas pelayanan publik/Public Service Obligation (PSO) dari pemerintah, yang diantaranya pengelolaan Cadangan Beras Pemerintah (CBP) dan penyaluran beras bersubsidi Raskin/Rastra.

Pengelolaan CBP dan Penyaluran beras Bersubsidi Raskin/Rastra telah lama sekali ditugaskan kepada BULOG, setidaknya terdapat 2 peraturan pemerintah sebagai dasar hukum BULOG dalam melakukan tugas itu, yaitu: (i) Inpres Nomor 5 Tahun 2015 tentang Kebijakan Pengadaan Gabah/Beras dan Penyaluran Beras Oleh Pemerintah; (ii) Peraturan Presiden Republik Indonesia Nomor 48 Tahun 2016 tentang Penugasan BULOG Dalam Rangka Ketahanan Pangan Nasional.

Dari kedua peraturan pemerintah terkait tugas BULOG tersebut, oleh penulis dirangkum menjadi diantaranya: (i) pengadaan dan penyaluran beras bersubsidi bagi kelompok masyarakat berpendapatan rendah dan; (ii) stabilisasi harga dan pengelolaan Cadangan Beras Pemerintah (CBP).

Menurut Peraturan Menteri Pertanian Republik Indonesia Nomor 11/Permentan/KN.130/4/2018 tentang Penetepan Jumlah Cadangan Beras Pemerintah Daerah, maksud dari Cadangan Beras Pemerintah yang selanjutnya disingkat CBP adalah persediaan beras yang dikuasai dan dikelola oleh pemerintah.

Sedangkan menurut Peraturan Menteri Perdagangan Republik Indonesia, Nomor 04/M-DAG/PER/1/2012 tentang Penggunaan Cadangan Beras Pemerintah untuk Stabilitasi Harga, Cadangan Beras Pemerintah adalah sejumlah tertentu beras milik Pemerintah Pusat yang pengadaannya didanai oleh Anggaran Pendapatan dan Belanja Negara (APBN) dengan arahan pernggunaan untuk penanggulangan keadaan darurat, kerawanan pangan, dan untuk memenuhi kesepakatan kerjasama internasionla serta keperluan lainnya yang ditetapkan Pemerintah. Masih dalam peraturan yang sama, stabilitasi harga adalah tindakan yang dilakukan untuk mencegah terjadinya lonjakan harga yang dapat meresahkan masyarakat setelah melakukan upaya pemantauan dan evaluasi perkembangan harga. Pemberian tugas pelayanan publik dari pemerintah kepada BULOG sangat erat kaitannya dengan kebijakan pemerintah dan kebijakan pemerintah ini sangat rentan dengan perubahanperubahan dari waktu-kewaktu yang dipengaruhi oleh banyak faktor untuk disesuaikan.

Kebijakan pemerintah terkait ketahanan pangan nasional berupa program Bansos Rastra dan BPNT, keduaduanya menggunakan alokasi pendanaan dari APBN.Ditargetkan kedepannya, bantuan akan lebih ditekankan dan lebih besar tugas pendistribusiannya melalui Program BPNT. Walaupun masih dalam tahap awal pelaksanaan, saat ini program BPNT telah berjalan, berkembang dan bertransisi sangat cepat dan mengambil porsi alokasi yang jauh lebih besar dari Program Bansos Rastra sebelumnya.

Bahkan dalam sebuah arahan Presiden Republik Indonesia, Joko Widodo dalam Rapat Terbatas Tentang Program Raskin 19 Juli 2016, agar penyaluran Raskin digantikan dengan menggunakan kartu elektronik yang akan diberikan langsung kepada rumah tangga sasaran, Kartu elktronik tersebut digunakan untuk mengdapatkan bahan pangan.Dan kini arahan tersebut telah terlaksana dalam program BPNT, bahkan 
bukanlah hal yang tidak mungkin bila program Bansos Rastra nanti dalam pendistribusiannya beralih melalui BPNT seluruhnya.

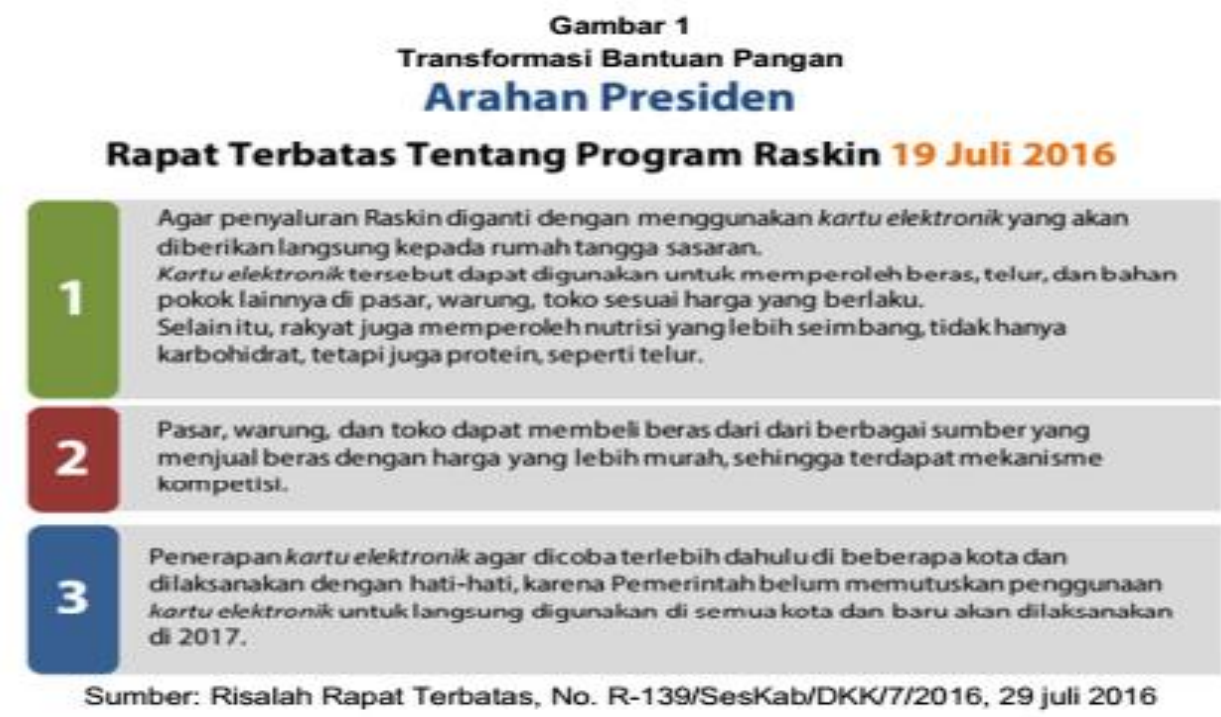

Dengan penyaluran bantuan yang tidak hanya melalui Program Bansos Rastra tetapi kini bantuan juga disalurkan melalui Program BPNT, maka penulis melihat permasalahan dan tantangan muncul pada BULOG untuk dipertanyakan, yang diantaranya:

(i) Adakah pengaruh terhadap kinerja operasional distribusi beras oleh BULOG, pasca Program Bansos Rastra dan BPNT berjalan?

(ii) Kegiatan operasional BULOG apa saja yang terpengaruh, pasca Program Bansos Rastra dan Program BPNT berjalan?

(iii) Apa saja yang perlu dilakukan BULOG, menghadapai tantangan kebijakan bantuan pangan pemerintah, khususnya Program BPNT?

Dan untuk selanjutnya, dijadikan sebagai bahan penelitian oleh penulis. Sebagai batasan penelitian, penulis melakukan pembatasan hanya pada beberapa hal yang berkaitan dengan Program Bansos Rastra, BPNT dan Laporan Tahunan BULOG tahun 2017 terutama pada bagian laporan kinerja operasional pelayanan publik komoditas pangan khususnya beras.

Tujuan penelitian ini ialah untuk:

(i) Mengetahui pengaruh kebijakan pemerintah pasca berjalannya Program Bansos Rastra dan Program BPNT, bagi kinerja operasional distribusi beras BULOG dalam tugas pelayanan publik;

(ii) Mengetahui kegiatan operasional BULOG apa saja yang terpengaruh;

(iii) Mengetahui apa saja yang perlu dilakukan BULOG, dalam menghadapai tantangan kebijakan bantuan pangan pemerintah khususnya Program BPNT. 
Adapun manfaat kegunaan penelitian ini adalah bisa dijadikan sebagai sumber referensi kebijakan pemerintah khususnya BULOG dalam hal memperthakankan dan meningkatkan kinerja operasional usahanya pada komoditas pangan, dan lain-lain.

\section{METODOLOGI}

Menurut Sugiyono (1999:1), Metode penelitian pada dasarnya merupakan cara ilmiah untuk mendapatkan data dengan tujuan dan kegunaan tertentu. Metode yang digunakan penulis dalam melakukan penelitian ini adalah menggunakan analisis data gabungan antara kualitatif dan kuantitatif. Dimana jenis data yang diteliti termasuk kualitatif karena data yang berbentuk kata, kalimat, skema, gambar. Sedangkan jenis data yang diteliti termasuk kuantitatif karena data yang berbentuk angka atau data yang diangkakan.

Dalam penelitian ini, sumber data yang digunakan adalah data sekunder yang merupakan data yang diperoleh peneliti secara tidak langsung dan dari kajian beberapa jurnal, artikel, peraturan-peraturan pemerintah, data perusahaan, internet dll. Yang dianggap relevan dengan topik bahasan penelitian.

\section{HASIL DAN PEMBAHASAN}

Ketahanan Pangan dan Kesejahteraan merupakan pembahasan dan topik bagi hampir seluruh negara dibelahan dunia. Pangan merupakan kebutuhan dasar manusia palng utama dan pemenuhannya merupakan bagian dari hak asasi setiap manusia yang dijamin oleh Undang-Undang Dasar Negara Republik Indonesia Tahun 1945.

Sejalan dengan amanat Undang-Undang Nomor 18 Tahun 2012, bahwa negara berkewajiban untuk mewujudkan ketersediaan, keterjangkauan, dan pemenuhan konsumsi pangan yang cukup, aman, bermutu, dan bergizi seimbang, baik pada tingkat nasional maupun daerah hingga perseorangan secara merata di seluruh wilayah Negara Kesatuan Republik Indonesia sepanjang waktu dengan memanfaatkan sumber daya, kelembagaan dan budaya lokal. Dalam hal upaya peningkatan kesejahteraan dan ketahanan pangan, pemerintah telah sejak lama melakukan program bantuan pangan.

Program bantuan pangan pemerintah dalam melakukan peningkatan kesejahteraan masyarakat dan dalam usaha ketahanan pangan nasional, mulai tahun 2017 tidak lagi dilakukan hanya melalui penyaluran beras subsidi kepada masyarakat yang telah sejak lama kita kenal dengan Program Raskin/Rastra.

Raskin/Rastra kinipun telah bertransformasi menjadi Program Bantuan Sosial Pangan (Bansos Pangan) yang terdiri dari Bantuan Sosial Beras Sejahtera (Bansos Rastra) dan Bantuan Pangan Non Tunai (BPNT). Kebijakan program ini pun terus berubah-ubah sesuai perkembangan zaman dan kebutuhan, tentunya guna pencapaian yang lebih baik dari waktu kewaktu. 


\section{Gambar 2 \\ Transformasi Bantuan Pangan \\ Transformasi Bantuan Pangan \\ (dari Subsidi menjadi Bansos)}

2016

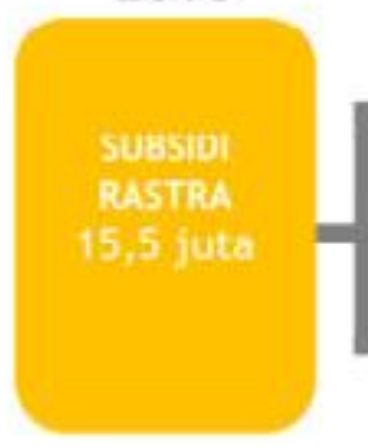

Sumber : Materi Sosialisasi Bantuan Pangan Non Tunai (BPNT) 2018

\section{Lahirnya Bantuan Pangan Non Tunai (BPNT)}

Boleh dikatakan program ini adalah tindak lanjut dari arahan Presiden Joko Widodo kepada jajaran menterinya tentang pengembangan program Raskin pada Juli 2016. Program ini bisa dikatakan inovasi baru dalam hal penyaluran pangan, karena dalam penyaluran ini melibatkan perbankan dan juga mengembangkan kewirausahaan masyarakat dalam membuka kelompok usaha bersama melalui Program Keluarga Harapan yang sebelumnya juga sudah berjalan melalui Kementerian Sosial sejak beberapa tahun sebelumnya.

Tahun 2017, Program bantuan melalui Program BPNT mulai dijalankan dan dijajaki. BPNT adalah bantuan dana pangan dari pemerintah sebesar Rp. 110.000,-/bulan yang diberikan kepada KPM setiap bulannya dengan mekanisme akun elektronik melalui Kartu Keluarga Sejahtera (KKS) yang digunakan hanya untuk membeli produk pangan di Elektronik Warung Gotong Royong, Kelompok Usaha Bersama, Program Keluarga Harapan (e-Warong KUBE PKH)/pada pedagang bahan pangan yang bekerjasama dengan Bank HIMBARA (Himpunan Bank Milik Negara).

Dalam sebuah Kajian Awal Pelaksanaan Program e-Warong Kube-PKH oleh Mawardu, Budianim, dkk. (2017) Penekanan penyaluran bantuan pangan oleh pemerintah melalui BPNT ini bukan tanpa alasan, penyaluran melalui BPNT bertujuan:

(i) Mewujudkan sistem finansial nasional yang inklusif;

(ii) Penyaluran semua Bansos dan Subsidi secara nontunai dengan menggunakan sistem perbankan akan memudahkan kontrol dan pemantauan serta mengurangi penyimpangan;

(iii) Meningkatkan ketepatan sasaran dan waktu penerimaan Bantuan Sosial; 
(iv) Mengurangi beban pengeluaran KPM melalui pemenuhan sebagian kebutuhan pangan dan;

(v) Memberikan lebih banyak pilihan dan kendali kepada KPM dalam memenuhi kebutuhan pangan.

Pemerintah terus mengembangkan penyaluran bantuan pangan melalui program ini, bahkan ditargetkan panyaluran bantuan pangan akan lebih banyak disalurkan melalui mekanisme Program BPNT ini dibandingkan melalui program bantuan lainnya.

\section{Trasnformasi Bantuan Subsidi Raskin/Rastra menjadi Bansos Rastra}

Bantuan Pangan sudah sejak lama dilakukan pemerintah dan sudah sangan dikenal masyarakat dengan nama Program Raskin (Beras untuk Rakyat Miskin).

Raskin merupakan bantuan subsidi harga pangan untuk masayarakat yang besaran nilai subsidinya ditetapkan pemerintah, sehingga masyarakat yang menerima bantuan masih harus membayar harga/biaya tebus tertentu untuk mendapatkannya.

Besaran kuantitas jumlah beras yang diterima oleh KPM adalah $15 \mathrm{~kg}$. Seiring berjalannya waktu, sejak 2015 pemerintah mengubah namanya menjadi Program Rastra (Beras Sejahtera).

Kini tahun 2018 program itupun bertransformasi dari pola batuan subsidi harga pangan berubah menjadi pola bantuan sosial, sekarang Keluarga Penerima Manfaat (KPM) mendapatkan beras kualitas medium dengan kuantitas $10 \mathrm{~kg}$ namun tidak dikenakan harga/biaya tebus. Dan kini nama programnya pun adalah Bansos Rastra. Telah sejak lama dalam melakukan penyaluran bantuan melalui produk beras ini, pemerintah menugaskan kepada BULOG untuk melakukan pendistribusian sebagai menjalankan fungsi tugas peyanan masyarakat. Mulai sejak nama program masih bernama Raskin hingga kini nama programnya bernama Bansos Rastra. Jika pada program Raskin/Rastra bantuan pangannya berupa beras dan pendistribusiannya ditugaskan kepada BULOG, maka untuk BPNT bantuan pangannya berupa dana belanja pangan dan pendistribusiannya melalui mekanisme transfer elektronik sistem perbankan melalui Bank HIMBARA. Walupun BPNT pendistribusiannya bukan melului BULOG, namun bantuan dana pangan BPNT bisa digunakan oleh KPM untuk membeli kebutuhan pangan produk BULOG.

\section{Kinerja Opersional Distribusi Beras BULOG Pasca Bansos Rastra dan BPNT}

Dalam Laporan Tahunan BULOG, tahun 2017. BULOG mencatatkan laporan kinerja operasionalnya ditahun 2016 sebelum Program BPNT berjalan, penyaluran bahan pangan beras untuk pelayanan publik sejumlah total sekirtar 3,2 Juta ton. Dari total tersebut, sekitar 2,8 juta ton atau $87 \%$-nya adalah penyaluran beras untuk program Raskin/Rastra. 


\section{Gambar 3}

Laporan Kinerja Operasional BULOG

\section{KINERJA OPERASIONAL}

Operational Performance

\begin{tabular}{|c|c|c|c|c|c|c|}
\hline 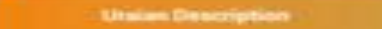 & zor: & 2013 & 2024. & 2015. & 2018 & angr \\
\hline \multicolumn{7}{|l|}{ Nonangater } \\
\hline 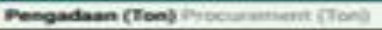 & 5.130 .643 & 3.758 .209 & 2624700 & 2611583 & 3510.101 & 2.051341 \\
\hline -Gabah fSetare Beras) & 210.232 & $200.27 \mathrm{~s}$ & 106.067 & $100.02 a$ & 136.153 & 220070 \\
\hline - Eeran DN & 3.205 .122 & 2.284 .227 & $2200-205$ & 1.858 .475 & 2.845353 & $x \operatorname{sen}-6 n$ \\
\hline Heras LN & varssozr & sues.rar & zresor & bas ves & 548.404 & \\
\hline Angraburan (Tom) & 12200.730 & 2631.451 & 2.109 .959 & 2.554800 & 2.232 .902 & 2716.900 \\
\hline 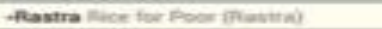 & 3.372819 & 2.431 .615 & 2774.269 & 2.202022 & $2 \pi 82.325$ & 2.542 .05 \\
\hline Colonge- Angowin & $122 \mathrm{Ta0}$ & 125016 & 12472 & $91.5 \pi$ & 110.120 & 102604 \\
\hline cep apsi & 273873 & 62.300 & 195.768 & 249 rot & $31154 a$ & TI:Fs \\
\hline tan-tam Oethers & 2.700 & 12.2200 & esso & $11.5 e 0$ & asoos & - \\
\hline 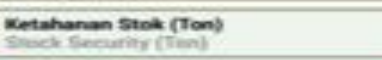 & $2.3200 \mathrm{rm}$ & 2109.456 & 1.679 .800 & 1.224712 & 3.612 .194 & 345.537 \\
\hline \multicolumn{7}{|l|}{ 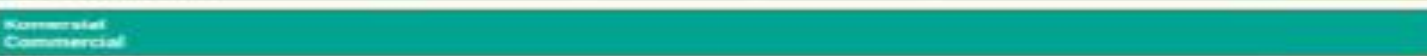 } \\
\hline 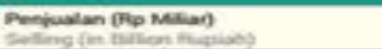 & 4.408 & 5350 & 5.45 & 13070 & 7.962 & 2.561 \\
\hline $\begin{array}{l}\text { Perdapangan } \\
\text { Tentivg }\end{array}$ & 1.014 & Seit & 1.394 & 7.159 & 6.260 & 2.725 \\
\hline 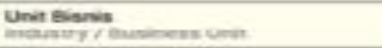 & 2.254 & 3.343 & 3.431 & L.75a & 240 & 138 \\
\hline 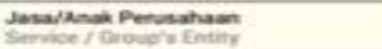 & 1.130 & 1.306 & 1.740 & 1.244 & 2.454 & 2005 \\
\hline
\end{tabular}

Sumber: Perum BULOG. 2018. Laporan Tahunan 2017. Jakarta.

Pada tahun 2017, pemerintah dalam menyalurkan bantuan pangan tidak hanya mengandalkan pada Program Rastra yang telah berjalan sejak sangat lama. Saat itu pemerintah mulai menggagas dan menjalankan alternatif program bantuan pangan lainya yang bernama Bantuan Pangan Non Tunai (BPNT).

Ditahun awal berjalannya, BPNT melakukan penyaluran bantuan pangan kepada 1.2 juta KPM. Besaran angka penyaluran tersebut berasal dari total 15,5 juta KPM sasaran dari program Rastra pada tahun sebelumnya, sehingga pada tahun tersebut Program Rastra hanya menyalurkan bantuan kepada 14,3 Juta KPM.

Otomatis dalam laporan kinerja opersional BULOG pada tahun 2017 mengalami penurunan pada data penyaluran beras untuk pelayanan publik menjadi sekitar 2,5 Juta ton.

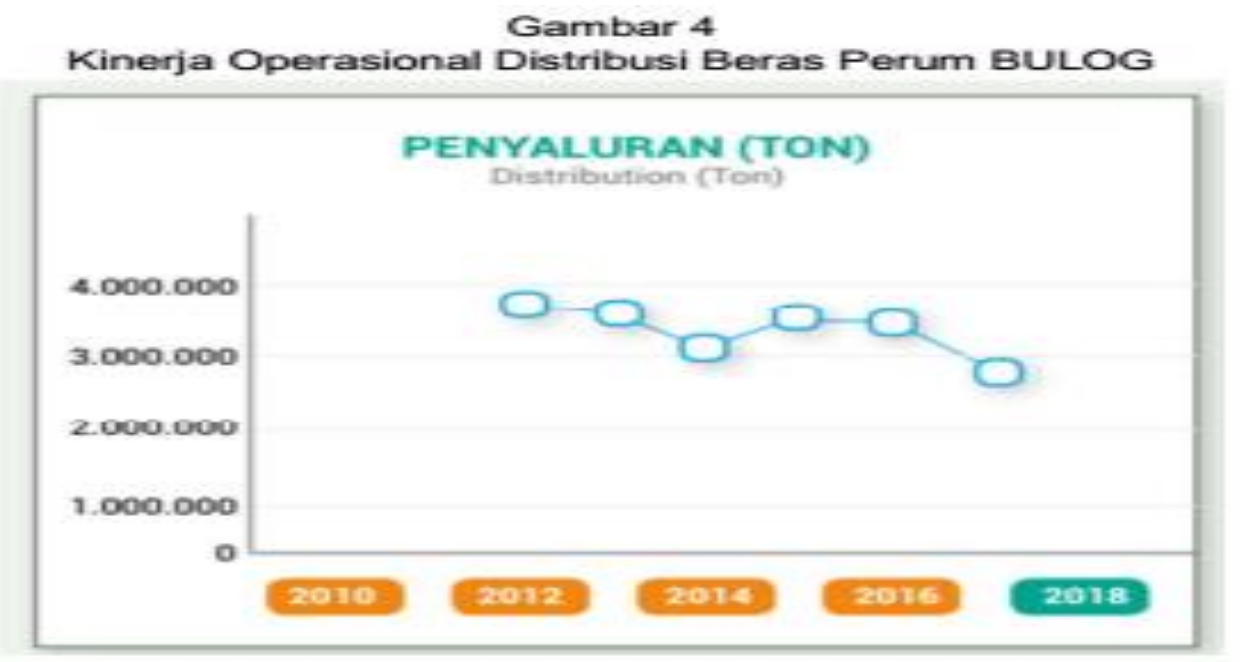

Sumber: Perum BULOG. 2017. Laporan Tahunan 2017. Jakarta 
BULOG sebagai salah satu Badan Usaha Milik Pemerintah (BUMN) berbentuk Perusahaan Umum yang bergerak dibidang logistik pangan, harus beradaptasi sangat cepat dan segera melakukan strategi inovasi guna mempertahankan kinerja operasionalnya pada usaha produk pangan yang dikelolanya, khusunya beras.

Pasalnya, tugas yang diberikan pemerintah kepada BULOG dalam hal ketahanan pangan sesuai inpres nomor 5 tahun 2015 terkait pengadaam dan penyaluran beras bersubsidi bagi masyarakat melalui Program Beras Sejahtera (Rastra) terus dikurangi. Penyaluran Program Rastra yang sebesar 3,2 Juta Ton tahun 2015, turun menjadi 2,5 Juta Ton pada tahun 2017 atau dengan kata lain berkurang sebesar 22\% sejak 2015.

Terlebih lagi, berdasarkan Kementerian Koordinator Bidang Pembangunan Manusia dan Kebudayaan. Siaran Pers Nomor: 61/Humas PMK/III/2018, di Jakarta tanggal 20 Maret 2018.

Pemerintah akan memperluas program Bantuan Pangan Non Tunai (BPNT) pada tahun ini hingga mencapai target 10 juta Keluarga Penerima Manfaat (KPM). Untuk tahap awal, perluasan BPNT tersebut direncanakan akan dilaksanakan di 24 Kabupaten/Kota. Itu berarti tugas publik yang akan diemban BULOG dalam menyalurkan beras program Rastra hanya tersisa untuk 5,5 juta KPM.

Secara analisa matematis apabila target pemerintah tercapai tahun 2018 ini dan tidak ada perubahan kebijakan dari pemerintah serta dengan kuantitas beras yang diterima adalah tetap $10 \mathrm{~kg} / \mathrm{KPM}$ pada penyaluran beras program Bansos Rastra, maka ditahun depan atau tahun 2019 beras yang akan didistribusikan BULOG untuk Bansos Rastra nanti hanya 660.000 ton.

Padahal penyaluran beras yang dilakukan BULOG untuk program Rastra mendominasi aktivitas operasional BULOG pada tahun-tahun sebelumnya, terutama dalam hal tugas BULOG melaksanakan Public Servic Obligation (PSO) dari pemerintah.

BPNT merupakan inovasi cara baru yang dilakukan pemerintah terkait penyaluran bantuan pangan yang sejak telah lama dilakukan secara konvensional berupa pemberian bantuan produk pangan berupa beras dan disalurkan melalui BULOG.

Kebijakan pemerintah terkait penyaluran bantuan pangan melalui BPNT, memberikan pengaruh secara langsung kepada Kinerja Operasional BULOG pada bidang usahan komoditas pangannya, karena pada Program BPNT penyaluran bantuan kepada KPM-nya merupakan bagian dari alokasi jumlah total KMP Rastra pada tahun sebelumnya yang pendistribusiannya seluruhnya dilakukan oleh BULOG. Dan kini penyaluran BPNT tidak dilakukan oleh BULOG tetapi melalui transaksi perbankan melalui Bank HIMBARA.

Table 1

Rasio Pendistribusian Rastra

\begin{tabular}{|c|c|c|c|c|c|c|}
\hline Deskripsi/Tahun & $\mathbf{2 0 1 2}$ & $\mathbf{2 0 1 3}$ & $\mathbf{2 0 1 4}$ & $\mathbf{2 0 1 5}$ & $\mathbf{2 0 1 6}$ & $\mathbf{2 0 1 7}$ \\
\hline Penyaluran (ton) & $3,720,130$ & $3,631,151$ & $3,103,959$ & $3,554,883$ & $3,212,802$ & $2,716,909$ \\
\hline Raskin/Rastra (Ton) & $3,372,819$ & $3,431,615$ & $2,774,869$ & $3,202,022$ & $2,782,326$ & $2,542,405$ \\
\hline Penyaluran (\%) & \multicolumn{7}{|l|}{} \\
\hline Rastra/Raskin & $\mathbf{9 1 \%}$ & $\mathbf{9 5 \%}$ & $\mathbf{8 9} \%$ & $\mathbf{9 0 \%}$ & $\mathbf{8 7 \%}$ & $\mathbf{9 4 \%}$ \\
\hline Lain-Lain & $9 \%$ & $5 \%$ & $11 \%$ & $10 \%$ & $13 \%$ & $6 \%$ \\
\hline
\end{tabular}

Sumber : Olah Data Perum BULOG, Laporan Tahunan 2017. Jakarta 


\section{Kegiatan Operasional BULOG Yang Terpengaruh, Pasca Program Bansos Rastra dan BPNT}

Berdasarkan beberapa kajian ilmu tentang logistik dan manajemen logistik. Christopher (2005) menjelaskan pengertian logistik adalah proses yang secara strategis mengelola pengadaan, pergerakan, dan penyimpanan material, suku cadang dan barang jadi beserta aliran informasi terkait melalui organisasi dan kanal-kanal pemasarannya, dalam cara dimana keuntungan perusahaan, baik untuk saat ini maupun diwaktu yang akan datang, dapat dimaksimalkan dengan cara pemenuhan pesanan yang berbiaya efektif.

Menurut Dwiantara dan Hadi (2004) Manajemen logistik merupakan serangkaian kegiatan perencanaan, pengorganisasian, dan pengawasan terhadap kegiatan pengadaan pencatatan, pendistribusian, penyimpanan, pemeliharaan dan penghapusan logistik guna mendukung efektivitas dan efisiensi dalam upaya pencapaian tujuan organisasi.

Sedangkan menurut Martono (2015:2) Manajemen Logistik yang kemudian berkembang menjadi manajemen Rantai Pasok adalah sistem terintegrasi yang mengkoordinasikan keseluruhan proses di organisasi/perusahaan dalam menyiapkan dan menyampaikan produk/jasa kepada konsumen yang mencakup perencanaan, sumber input bagi proses, proses transformasi input menjadi output, transportasi, distribusi, pergudangan, sistem informasi dan pembayaran produk/jasa, sampai produk/jasa tersebut dikonsumsi oleh konsumen, serta layanan pengembalian produk/jasa. Dengan perubahan kebijakan pemerintah yang melakukan penyaluran bantuan pangan dengan proporsi lebih besar melalui Program BPNT dibandingkan melalui Program Bansos Rastra yang penyalurannya dilakukan oleh BULOG.

Dengan kata lain bahwa kegiatan distribusi BULOG jauh dikurangi, maka dalam kinerja operasional BULOG tidak hanya kinerja opersional dari kegiatan distribusi/penyaluran saja yang menurun, malainkan seluruh bagian/kegiatan rantai pasok yang berkaitan dengan kegiatan distribusi juga akan terpengaruh dan mengalami penurunan kinerja operasional.

\section{Tantangan Bagi BULOG Pasca Bansos Rastra dan BPNT}

Berfokus kepada aktivitas operasional BULOG yang terus menurun dikarenakan tugas publiknya dalam hal penyaluran Rastra yang jauh berkurang dan guna mempertahankan aktivitas operasionalnya agar tetap tinggi.

Kini saatnya BULOG mengoptimasi bisnis komersialnya, karena BULOG sebagai BUMN yang memiliki fungsi tugas Public Service Obligation (PSO), BULOG juga memiliki fungsi komersial yang harus memiliki pendapatan untuk menjalankan operasi dan mengembangkan BULOG secara mandiri.

Tantangannya, BULOG harus lebih bisa berkompetensi dengan sistem persaingan pasar dengan berbagai pengembangan kompetensinya, diantaranya adalah produk yang unggul, harga yang murah, jangkauan produk, distribusi yang cepat, serta layanan akan menjadi kunci suksesnya.

Walaupun BULOG telah memiliki beberapa unit usaha komersial, namun rasio aktivitas operasional dari usaha komersialnya masih sangat kecil dibandingkan seluruh kinerja operasional BULOG itu sendiri. 
Bahkan masih sangat kecil jika kinerja operasional usaha komersialnya dibandingkan dengan kinerja opersional dalam menjalankan fungsi tugas pelayanan publik/PSO dari pemerintah. Bila diasumsikan BULOG melakukan melakukan operasional usaha tanpa menjalankan tugas PSO dari pemerintah yang dibiayai dari APBN, maka akan terasa sangat berat bila pendapatan dari bisnis usaha komersial saat ini harus digunakan untuk menopang seluruh operasional BULOG dengan Kapasiatas Perusahaan, Infrastruktur dan Sumber Dayanya yang sudah sangat besar.

Namun dengan kapasitas organisasi, sumber daya, infrastruktur pergudangan dan sebarannya serta pengalaman penanganan komoditas pangan, BULOG seharusnya mampu melakukan pengembangan dan optimasi usaha komersial untuk bersaing dipasar pada bidang komoditas pangan secara unggul.

Dalam bisnis komoditas pangan secara komersialnya, BULOG telah melakukan (i) distribusi penjualan tidak langsung ke pasar tradisional maupun modern, distributor/agen serta ritel; (ii) distribusi penjualan langsung melalui direct sales ke konsumen Hotel, Restoran dan Katering yang mereka sebut (HOREKA) dan; (iii) melakukan penjualan Program Kemitaraan berupa Rumah Pangan Kita (RPK) dan Toko Baitul Pangan (TOBATAN) yang merupakan agen mitra binaan BULOG. Dan kini, dengan program Bansos Pangan pemerintah melalui BPNT, kedepannya akan makin banyak tumbuh e-Warong dan e-Warong sendiri merupakan agen penjualan komoditas pangan produk BULOG.

Yang perlu digarisbawahi, dengan BPNT masyarakat memiliki kebebasan memilih dalam membeli produk bahan pangan yang diinginkan dari berbagai pilihan produk, merek dan distributor yang tersedia di agen/toko.

Tidak seperti program Rastra sebelumnya, dimana PKM tidak ada pilihan alternatif dalam menerima produk beras yang diberikan pemerintah melalui BULOG.

Saat ini tinggal seberapa cepat BULOG beradaptasi, berinovasi dan meningkatkan kompetensinya sebagai bagian melakukan strategi pengembangan dan optimasi bisnis komoditas komersialnya untuk bersaing dipasar bidang komoditas pangan secara unggul.

Karena kini tidak ada alasan lagi bagi BULOG dalam mengembangkan potensi bisnis komersialnya secara maksimal. Yang mungkin pada waktu sebelumnya dalam hal melaksanakan tugas program Rastra dari pemerintah dijadikan alasan besarnya sumber daya dan aktivitas operasi terpakai. Transformasi program Subsidi Rastra yang kini menjadi Bansos Pangan yang terdiri dari Bansos Rastra dan BPNT dengan kapasitas BPNT yang jauh lebih besar, akan menjadi program "Pil Pahit" bagi BULOG yang memungkinkan berdampak penurunan aktivitas operasionalnya. Namun setidaknya pil pahit tersebut bukanlah racun mematikan, melainkan sebaiknya disikapi sebagai pil pahit obat yang menyembuhkan BULOG dari ketergantungan selama ini yang kegiatannya opersionalnnya didominasi dan mengandalkan tugas dari pemerintah seperti Program Rastra yang dibiayai APBN.

Setidaknya, BULOG dalam melakukan pengembangan bisnis komersialnya kini tidak mulai dari nol, karena sebenarnya BULOG telah memiliki beberapa unit bisnis komersial dan anak perusahaan selain bidang komoditas pangan. Dilain sisi berdasarkan Perpres 48 tahun 2016, pemerintah masih memberikan tugas khusus publik kepada BULOG dalam hal melakukan pengelolaan Cadangan Beras Pemerintah (CBP), dimana penulis mengelompokan tujuan penggunaan CBP diantaranya untuk: (i) Operasi Pasar dalam hal penanganan 
kekurangan pangan dan stabilitasi harga pangan; (iii) keadaan darurat, bencana dan rawan pangan; (iv) Kerjasama internasional dan atau pemberian bantuan pangan luar negeri; (v) serta keperluan lain yang ditetapkan pemerintah.

\section{KESIMPULAN}

Dengan berjalannya kebijakan bantuan pangan pemerintah melalui program Bansos Rastra dan BPNT sebagai transformasi program sebelumnya yaitu Rastra, dimana penyaluran bantuan pangan jauh lebih besar proporsi penyalurannya melalui program BPNT yang melalui transaksi perbankan HIMBARA, dibandingkan dengan penyaluran bantuan pangan melalui program Bansos Rastra yang didistribusikan oleh BULOG.

Maka pasca kebijakan pemerintah tersebut menyebabkan pengaruh secara langsung terhadap kinerja operasional distribusi pada BULOG yang menjadi menurun. Dikarenakan selama ini aktivitas operasional BULOG sangat bergantung dan didominasi oleh kegiatan palaksanaan tugas publik dari pemerintah terutama penyaluran Raskin/Rastra dibandingkan kegiatan usaha komersial BULOG sendiri.

Perubahan kebijakan pada suatu bagian rantai pasok akan menyebabkan perubahan pula pada bagian rantai pasok lainnya, karena sistem rantai pasok saling terintegrasi. Sehingga perubahan kebijakan terkait kegiatan penyaluran, akan mempengaruhi kinerja operasional kegiatan pada bagian penyaluran itu sendiri dan juga mempengaruhi kinerja operasiona kegiatan pada bagian lainnya. Dalam hal perubahan kebijakan penurunan jumlah penyaluran beras melalui Program Rastra yang didistribusikan oleh BULOG, maka penurunan kinerja operasional tidak hanya terdapat pada kegiatan penyaluran, melainkan juga pada kegiatan: pengadaan, pengeloaan, peyimpanan, dan kegiatan lain yang saling terkait.

Disarankan kepada BULOG harus melakukan pengembangan dan optimasi kegiatan bisnis komersialnya guna mempertahankan kinerja operasionalnya karena pengurangan tugas publik dari pemerintah terkait perdistribusian Rastra.

Pengembangan dan optimasi kegiatan bisnis komersial BULOG, selain untuk mempertahankan kinerja operasionalnya juga untuk mempertahankan dan meningkatkan pendapatan yang pada akhirnya untuk menjalankan kegiatan operasional dan pengembangan usaha BULOG secara mandiri.

Mengingat BULOG telah memiliki organisasi, Infrastruktur dan sumber daya yang sudah sangat besar, sehingga kedepannya BULOG dari kegiatan usaha komersialnya bisa mandiri dan tidak bergantung pada pelaksanaan tugas pelayanan publik dari pemerintah. 


\section{DAFTAR PUSTAKA}

Richardus Eko, Richardus. 2003.Manajemen Persediaan. Jakarta: Grasindo.

Walters, Donald, 2003, Logistics: An Introduction to Supply ChainManagement, New York: Palgrave Mc Millan.

Dwiantara, Lukas \& Sumarto, Hadi Rumsari, 2004. ManajemenLogistik. Jakarta: Grasindo.

Subagya, M.S., 1994. Manajemen Logistik- cetakan keempat. Jakarta: PT. Gunung Agung.

Christopher, Martin. 2011. Logistics and Supply Chain Management Fourth Edition. London: Prentice Hall.

Subagya, M.S., 1994. Manajemen Logistik- cetakan keempat. Jakarta: PT. Gunung Agung.

Tjiptono, Fandy. 2014, Pemasaran Jasa - Prinsip, Penerapan, dan Penelitian. Yogyakarta: Andi Offset.

Martono, Ricky, 2015. Manajemen Logistik Terintegrasi. Jakarta: PPM Manajemen.

Mawardi, Ruhmaniyati, dkk. (2017). Kajian Awal Pelaksanaan Program e-Warong Kube-PKH. Jakarta: The SMERU Research.

Republik Indonesia. 2012. Undang-Undang Republik Indonesia Nomor 18 Tahun 2012 Tentang Pangan. Lembaran Negara RI Tahun 2012, Nomor 227. Sekretariat Negara. Jakarta.

Republik Indonesia. 2015. Peraturan Pemerintah Nomor 17 Tahun 2015 tentang Ketahanan Pangan dan Gizi. Lembaran Negara RI Tahun 2015, Nomor 60. Sekretariat Negara. Jakarta.

Republik Indonesia. 2015. Instruksi Presiden Nomor 5 Tahun 2015 tentang Kebijakan Pengadaan Gabah/Beras Dan Penyaluran Beras Oleh Pemerintah. Sekretariat Kabinet. Jakarta. 
Republik Indonesia. 2012. Peraturan Menteri Perdagangan Republik Indonesia, Nomor 04/M-

DAG/PER/1/2012 tentang Penggunaan Cadangan Beras Pemerintah untuk Stabilitasi Harga. Cadangan Beras Pemerintah. Jakarta.

Republik Indonesia. 2016. Peraturan Preiden Nomor 48 Tahun 2016 Tentang Penugasan Kepada Perum BULOG Dalam Rangka Ketahanan Pangan Nasional. Lembaran Negara RI Tahun 2016, Nomor 105. Sekretariat Kabinet. Jakarta.

Republik Indonesia. 2017. Peraturan Preiden Nomor 63 Tahun 2017 Tentang Penyaluran Bantuan Sosial Secara Non Tunai. Lembaran Negara RI Tahun 2017, Nomor 156. Sekretariat Kabinet. Jakarta.

Republik Indonesia. 2016. Risalah Arahan Presiden Dalam Rapat Terbatas Nomor R-

139/SesKab/DKK/7/2016. Tentang Program Raskin 29 juli 2016. Jakarta.

Kementerian Koordinator Bidang Pembangunan Manusia dan Kebudayaan (2018). Siaran Pers Nomor: 61/Humas PMK/III/2018, Jakarta 20 Maret 2018. (online), (https://www.kemenkopmk.go.id/pengumuman/siaran-pers-nomor-23humas-pmkii2018. Diakses pada 28 Oktober 2018).

Laman website resmi Perum BULOG, (online), (http://www.bulog.co.id/ketahananpangan.php Diakses Pada 28 Oktober 2018).

Petunjuk Teknis Pelaksanaan Bantuan Sosial Beras Sejahtera. 2018. (Online), (http://www.tnp2k.go.id/download/16760Materi\%20Sosialisasi\%20Bansos\%20Rastra\%202018.pdf. Diakses pada 28 Oktober 2018) .

Bantuan Pangan Non Tunai BPNT. 2018. Jakarta: Kementerian Sosial. (0nline), (https://www.kemsos.go.id/page/bantuan-pangan-non-tunai. Diakses pada 28 Oktober 2018)

Materi Sosialisasi Bantuan Pangan Non Tunai (BPNT). 2018. (Online), (http://www.tnp2k.go.id/download/38087Materi\%20Sosialisasi\%20BPNT\%202018.pdf. Dikases pada 28 Oktober 2018). 